\title{
Crop yield and nutrient balance influenced by shoot biomass management and pig slurry application
}

\author{
Carla M. Pandolfo ${ }^{1} \&$ Milton da Veiga ${ }^{1}$ \\ ${ }^{1}$ Empresa de Pesquisa Agropecuária e Extensão Rural de Santa Catarina/Estação Experimental de Campos Novos. Campos Novos, SC. E-mail: \\ pandolfo1710@gmail.com; milton.veiga.br@gmail.com (Corresponding author)
}

\author{
Key words: \\ black oat \\ rye \\ sorghum \\ corn \\ organic manure \\ silage \\ hay
}

\begin{abstract}
A B S T R A C T
Crop systems that export large amounts of nutrients from the farm may require higher doses of animal manure than those needed for grain production. This study aimed to evaluate the yield of crops and to determine the simplified nutrient balance in three management systems of shoot biomass of crops (cover-grain, cover-silage and hay-silage) associated with five fertilization treatments (control, soluble fertilizer and three doses of pig slurry). The experimental design was a split plot, arranged in randomized blocks with four replicates. The management systems of shoot biomass did not affect the yield of the winter pasture, but there was an increase in yield with the application of pig slurry. The summer crops responded differently to fertilization, depending on the purpose for which they were grown, whether for grain or silage. In the three management systems of shoot biomass, there was an excess of $\mathrm{Zn}$ and $\mathrm{Cu}$ from the application of $25 \mathrm{~m}^{3} \mathrm{ha}^{-1}$; $\mathrm{N}$ from $50 \mathrm{~m}^{3} \mathrm{ha}^{-1}$; and $\mathrm{P}, \mathrm{K}$ and $\mathrm{Ca}+\mathrm{Mg}$ at the dose of $100 \mathrm{~m}^{3} \mathrm{ha}^{-1}$.
\end{abstract}

Palavras-chave:
aveia-preta
azevém
sorgo
milho
adubação orgânica
silagem
feno

\section{Rendimento de cultura e balanço de nutrientes influenciados por manejos da fitomassa e dejetos suínos}

\section{R E S U M O}

Sistemas de culturas que exportam grandes quantidades de nutrientes da lavoura podem demandar doses mais altas de dejetos animais do que aquelas necessárias à produção de grãos. Objetivou-se avaliar o rendimento de culturas e determinar o balanço simplificado de nutrientes em três sistemas de manejo da fitomassa aérea das culturas (coberturagrãos, cobertura-silagem e fenação-silagem) associados a cinco tratamentos de adubação (testemunha, adubo solúvel e três doses de dejeto líquido de suínos). Os sistemas de manejo da fitomassa aérea não afetaram o rendimento de massa seca da pastagem de inverno mas houve incremento no seu rendimento com a aplicação de dejeto. As culturas de verão responderam de forma diferenciada à adubação, em função da finalidade para a qual foram cultivadas, se para grãos ou silagem. Nos três sistemas de manejo da fitomassa houve excedente de $\mathrm{Zn}$ e $\mathrm{Cu}$ a partir da aplicação de $25 \mathrm{~m}^{3} \mathrm{ha}^{-1}$; de $\mathrm{N}$ a partir de $50 \mathrm{~m}^{3} \mathrm{ha}^{-1}$ e de $\mathrm{P}, \mathrm{K}$ e Ca $+\mathrm{Mg}$ na dose de $100 \mathrm{~m}^{3} \mathrm{ha}^{-1}$. 


\section{INTRODUCTION}

Animal manure is a source of the major macro- and micronutrients required by crops and can be used in substitution of soluble fertilizers. In Southern Brazil, the three main species raised by farmers are cattle, pig and poultry, with high availability of their manure in some farms.

The application of pig manure as slurry (PS) increases the levels of N, P, K, Ca and Mg in the soil (Scherer et al., 2007; Veiga et al., 2012b) and in the crops (Choudhary et al., 1996; Cassol et al., 2012; Sartor et al., 2012; Scherer et al., 2012). Due to the low content of nutrients present in this manure (Scherer et al., 1996), the use of large volumes is usually necessary to provide enough amounts of plant nutrients. Cassol et al. (2012) found that corn production increased with doses of PS in an Oxisol and estimated that $90 \%$ of the maximum crop yield would be obtained by applying $84 \mathrm{~m}^{3} \mathrm{ha}^{-1}$. Doses of PS recommended by the Commission of Chemistry and Soil Fertility of the South Section of the Brazilian Society of Soil Science (SBCS, 2004) to supply nutrients to crops is based on the nutrient content in the soil, the nutritional requirements of the crop, the concentration of the nutrient in the manure and the efficiency ratio of each nutrient. However, the added doses very often exceed this recommendation due to the large availability of this manure on farms, the high cost of transport and the need of disposal of the excess volume. Annual applications of PS doses of $80 \mathrm{~m}^{3} \mathrm{ha}^{-1}$ or higher, in Oxisols and Ultisols, resulted in accumulation of nutrients in varying layers in depth (Ceretta et al., 2003; Assmann et al., 2007; Scherer et al., 2010; Veiga et al., 2012b). This demonstrates that the applied amounts have been greater than those exported by the crop in the form of grain or pasture, increasing the risk of damage to the environment.

The Normative Statement No. 11 of the Santa Catarina Environmental Foundation (FATMA, 2009) allows the maximum PS application in the soil of $50 \mathrm{~m}^{3} \mathrm{ha}^{-1} \mathrm{yr}^{-1}$, without considering its nutrient content, nutrient availability in the soil or crop requirement, only mentioning the need to perform soil analysis. Because of this, many farmers have difficulties finding areas for correct disposal of exceeding PS in their own or neighboring farms, indicating the need for studies to estimate the ability of soils to recycle this type of waste. The use of cropping systems including crops with high nutrient export, such as for hay or silage production, could make possible the increase of PS doses to be applied on crops without increasing the risk of damaging the environment. When corn is cut for silage, for instance, grains and almost all the shoot biomass are removed from the plants, leading to a high extraction and exportation of nutrients (Coelho, 2006), substantially increasing their removal compared with corn cultivated for grain production (Ueno et al., 2013).

The objective of this study was to evaluate the yield of winter pasture and summer crops and to calculate the simplified balance of some nutrients as a result of the management of crop shoot biomass and the application of PS doses or soluble fertilizer.

\section{Material ANd Methods}

The experiment was conducted at the Epagri's Experimental Station in the municipality of Campos Novos, Santa Catarina,

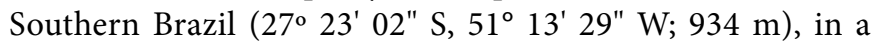
Hapludox soil. At the beginning of the experiment, the soil analysis in the $0-20 \mathrm{~cm}$ layer showed: $630 \mathrm{~g} \mathrm{~kg}^{-1}$ of clay; $30 \mathrm{~g}$ $\mathrm{kg}^{-1}$ of organic matter; 5.4 of $\mathrm{pH}$-water; 5.3, 6.6 and $0.7 \mathrm{mg}$ $\mathrm{dm}^{-3}$ of extractable $\mathrm{P}, \mathrm{Cu}$ and $\mathrm{Zn}$, respectively; $166 \mathrm{mg} \mathrm{dm}^{-3}$ of exchangeable $\mathrm{K}$; and 4.0 and $2.8 \mathrm{cmol}_{\mathrm{c}} \mathrm{dm}^{-3}$ of exchangeable $\mathrm{Ca}$ and $\mathrm{Mg}$, respectively.

The experimental design was a split plot, arranged in randomized blocks with four replicates. In the main plot, 5 x $25 \mathrm{~m}$, three management systems of shoot biomass were applied, simulating intensities of nutrients removal: CG (cover-grains): keeping the shoot biomass of winter pasture and removing summer crop grain; CS (cover-silage): keeping the shoot biomass of winter pasture and removing that from the summer crops, simulating silage; and HS (hay-silage): removal of shoot biomass from winter pasture and summer crops, simulating hay and silage production, respectively. In $5 \times 5 \mathrm{~m}$ subplots, five fertilization treatments were applied: $\mathrm{C}$ - control, without nutrient application; 25, 50 and $100 \mathrm{~m}^{3} \mathrm{ha}^{-1}$ of pig slurry (PS25, PS50 and PS100, respectively); and AS - N, $\mathrm{P}_{2} \mathrm{O}_{5}$ and $\mathrm{K}_{2} \mathrm{O}$ applied in amounts corresponding to PS50 in the form of soluble fertilizer. The fertilization treatments were applied on the surface before sowing winter pasture and summer crops, respectively in the fall and spring of each year. The sources of $\mathrm{N}, \mathrm{P}_{2} \mathrm{O}_{5}$ and $\mathrm{K}_{2} \mathrm{O}$ in the treatment with soluble fertilizer were, respectively, ammonium nitrate or urea, triple superphosphate and potassium chloride. The PS applied in this experiment is from digester units of termination pigs, whose average analytical results are shown in Table 1.

The crops and stand used in this study were: Year 1 color bean and Tifton (data used only for nutrient balance calculating); Year $2-80 \mathrm{~kg} \mathrm{ha}^{-1}$ of black oat Iapar 61 sown in rows spaced $0.17 \mathrm{~m}+30 \mathrm{~kg} \mathrm{ha}^{-1}$ of common ryegrass spread

Table 1. Physical and chemical characteristics of pig slurry applied in the period of experimentation (2009-2012)

\begin{tabular}{|c|c|c|c|c|c|c|c|c|c|}
\hline \multirow{2}{*}{ Application } & \multirow{2}{*}{$\mathrm{pH}$} & \multirow{2}{*}{$\begin{array}{c}\text { DM } \\
\%\end{array}$} & $\mathrm{~N}$ & $\mathrm{P}_{2} \mathrm{O}_{5}$ & $\mathrm{~K}_{2} \mathrm{O}$ & $\mathrm{Ca}$ & $\mathrm{Mg}$ & $\mathrm{Cu}$ & $\mathrm{Zn}$ \\
\hline & & & \multicolumn{5}{|c|}{$\mathrm{kg} \mathrm{m}^{-3}$} & \multicolumn{2}{|c|}{$\mathrm{g} \mathrm{m}^{-3}$} \\
\hline $1^{\text {st }} /$ spring & 8.3 & 2.1 & 3.8 & 1.2 & 2.2 & 0.8 & 0.8 & 57.2 & 72.1 \\
\hline $2^{\text {nd }} / f a l l$ & 6.6 & 2.9 & 2.2 & 0.3 & 1.0 & - & - & - & - \\
\hline $3^{\text {rd }} /$ spring & 6.7 & 3.8 & 4.1 & 2.1 & 1.8 & 0.7 & 0.6 & 48.0 & 75.3 \\
\hline $4^{\text {th }} /$ fall & 7.4 & 2.9 & 3.9 & 1.5 & 5.0 & 0.5 & 0.2 & 22.1 & 104.6 \\
\hline $5^{\text {th }} /$ spring & 7.5 & 2.3 & 3.5 & 1.4 & 2.6 & 0.4 & 0.2 & 29.1 & 54.8 \\
\hline $6^{\text {th }} /$ fall & 7.5 & 1.9 & 4.2 & 1.1 & 2.9 & 0.5 & 0.3 & 22.1 & 35.6 \\
\hline $7^{\text {th }} /$ spring & 7.6 & 1.7 & 2.9 & 1.1 & 2.0 & 0.4 & 0.4 & 8.8 & 28.4 \\
\hline Average & 7.4 & 2.5 & 3.5 & 1.2 & 2.5 & 0.6 & 0.4 & 31.2 & 61.8 \\
\hline
\end{tabular}

DM - Dry mass 
on surface/ corn P30F53 sown in rows spaced $0.5 \mathrm{~m}$ with 3.25 plants per linear meter; Year 3 - black oat + ryegrass (as in the previous year)/sorghum Qualimax PCT sown in rows spaced 0.5 m with 18 seeds per linear meter; Year 4 - oats + ryegrass/ corn (as in the previous years).

The winter pasture shoot biomass was collected at the time of full bloom in $0.25 \mathrm{~m}^{2}$ of soil area per plot. This biomass was dried in an oven with forced air circulation at $60^{\circ} \mathrm{C}$ until constant weight to determine shoot dry mass production. In the HS treatment, all the shoot green mass was cut to $0.1 \mathrm{~m}$ above the ground and removed from the plot, simulating the production of hay. To determine the production of sorghum or corn shoot green biomass in CS and HS treatments, the plants were cut at approximately $0.1 \mathrm{~m}$ from the surface in $6.0 \mathrm{~m}^{2}$ of soil area per plot when corn grains reached half of the $2 / 3$ milk line and the sorghum was at the dough point. After this sampling, the remaining biomass was removed from the plot.

The data of green biomass of maize and sorghum, dry mass of sorghum panicles and grain yield of maize are presented as relative yield for each parameter evaluated, considering $100 \%$ the greatest physical production of a plot in each biomass management system and harvest. The simplified balance of nitrogen $(\mathrm{N})$, phosphorus $(\mathrm{P})$, potassium $(\mathrm{K})$, calcium + magnesium $(\mathrm{Ca}+\mathrm{Mg})$, zinc $(\mathrm{Zn})$ and copper $(\mathrm{Cu})$ were determined by the difference between the amount applied via PS or AS and the amount of each nutrient exported by the crop shoot biomass, corn grain or sorghum panicles. Nutrient exportation was calculated by multiplying its content in each material and the respective yield obtained in each plot and year. In the simplified balance, exports by crops of beans and Tifton were also considered; these species were grown in the first year of the experiment and were not part of the review yields.

Data were subjected to analysis of variance, and the significance of the $\mathrm{F}$ test was verified considering the years of experimentation as parcels of the subplots. When significant differences between means $(\mathrm{p}<0.05)$ were observed, regression equations were developed between the fertilization treatments with PS and the relative yields of grain or crop biomass, at a significance level of $\mathrm{p}<0.05$.

\section{Results AND Discussion}

The management systems of shoot biomass did not affect the yield of the winter pasture, but there was response to doses of PS with different magnitude among years (Figure 1). Increase in the yield of the pasture was also verified by Assmann et al. (2007) in an Oxisol, similar to this experiment. They observed $34 \%$ increase in the production of accumulated dry matter in black oat and ryegrass at the dose of $80 \mathrm{~m}^{3} \mathrm{ha}^{-1}$ compared with the control. It was also verified by Scherer et al. (2012), who observed, besides the increase in production, improvement in the nutritional quality of winter pasture with the application of PS in another Hapludox. In our study, doses of PS for maximum technical efficiency (MTE) were 106, 96 and $81 \mathrm{~m}^{3} \mathrm{ha}^{-1}$ of dry matter yields with $8,012,12,843$ and $8,494 \mathrm{~kg} \mathrm{ha}^{-1}$ in the years 2010, 2011 and 2012, respectively. Crop response to high doses of PS was also observed by Ceretta et al. (2005), who determined around $85 \mathrm{~m}^{3} \mathrm{ha}^{-1}$ as the MTE dose for the production of oat dry matter and corn grain in an Ultisol.

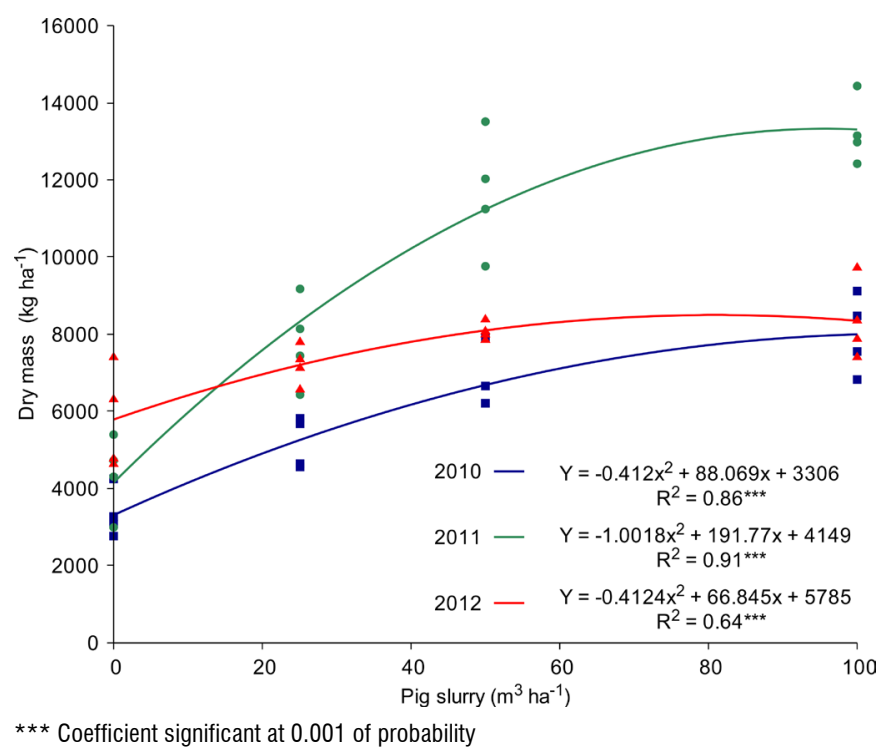

Figure 1. Dry mass production of winter pasture due to the application of doses of pig slurry (PS) twice a year in three evaluated cycles

The greater response of the pasture verified in 2011 is due to higher precipitation occurred from June to September of that year compared with the years 2010 and 2012, the period of growth and development of the winter pasture (Figure 2). These results agree with Fageria (1998), who claimed that water is the main biophysical production factor of annual crops and also in plant nutritional efficiency. The lower yields of dry mass obtained in 2010 may also be explained by lower amounts of $\mathrm{N}, \mathrm{P}$ and $\mathrm{K}$ added via PS in the fall of that year (Table 1). The decrease in doses of PS to achieve MTE over time suggests that there is a need of a longer period of observation with the application of biomass management systems to establish the final doses of MTE.

High relative yields of dry mass from pasture were obtained with the PS dose of $50 \mathrm{~m}^{3} \mathrm{ha}^{-1}$ in the years 2010, 2011 and 2012, reaching respectively 83,87 and $95 \%$ when compared with the yield obtained with the dose of MTE in the same years. However, the increase in yield of dry mass from pasture at 50 $\mathrm{m}^{3} \mathrm{ha}^{-1}$ (PS50) for the MTE dose was small. The yields of dry

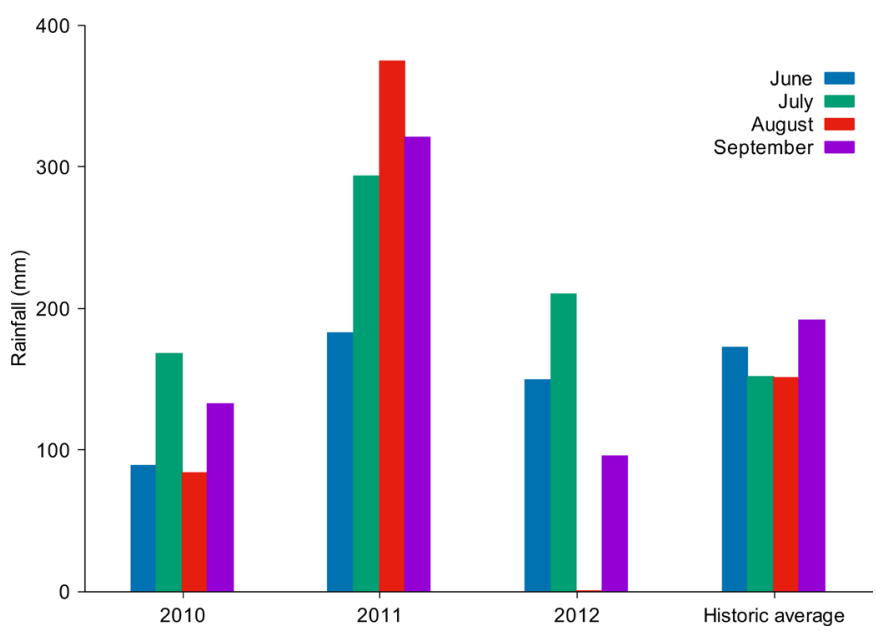

Figure 2. Monthly rainfall from June to September of 2010, 2011 and 2012, determined at the Meteorological Station of Epagri/Campos Novos, located at approximately $0.8 \mathrm{~km}$ from the experiment 
mass from pasture produced by the control (C) in relation to E50 were 41, 32 and 68\% in the years 2010, 2011 and 2012, respectively. Responses to the application of manure were also verified by Scheffer-Basso et al. (2008) on native pasture formed with Paspalum spp. and Axonopus spp. grown in an Ultisol with $11 \%$ clay, and by Scherer et al. (2012) on annual winter and summer grasses in an Oxisol with $63 \%$ clay. The response of plants grown in different soils to the application of animal manure confirms its fertilizing effect. Although the improvement of soil fertility is one of the highlighted benefits, they can also improve other aspects, such as soil structure and aeration (SBCS, 2004).

Considering the seven applications of PS, it was possible to notice that the response of systems with different intensities of biomass removal differed among doses (Figure 3 ). It is observed that the greatest response to fertilization occurred in the CG system, which confirms the high grain yield response to fertilization. The greater response in grain yield in relation to shoot biomass may be associated with a variation in the harvest index (ratio of grain yield and total plant dry matter), which decreases with decreasing crop productivity (Khaliq et al., 2004), and may have just straw production in extreme cases (Delougherty \& Crookston, 1979). This aspect is demonstrated by the relative yields of grain in C, PS50 and PS100, which were respectively 23,70 and $92 \%$ in the CG system, while the relative yields of green matter were respectively 45,80 and $89 \%$ in CS system, and 47, 68 and $88 \%$ in the HS system.

The sum of applications of PS25 treatment twice a year, performed in the fall and spring, account for the maximum annual dose allowed by the legislation (FATMA, 2009). By applying this dose in summer crops, 50, 66 and 58\% of relative grain yield or green mass were obtained in the three harvests studied, respectively in CG, CS and SS systems. These yields are much lower when compared with the application of a dose such as $50 \mathrm{~m}^{3} \mathrm{ha}^{-1}$, indicating the need for application of larger doses of PS to obtain adequate yields of grain and silage. Although the HS system has higher yield on the test in relation to the CG system, the best fit was that of the linear regression

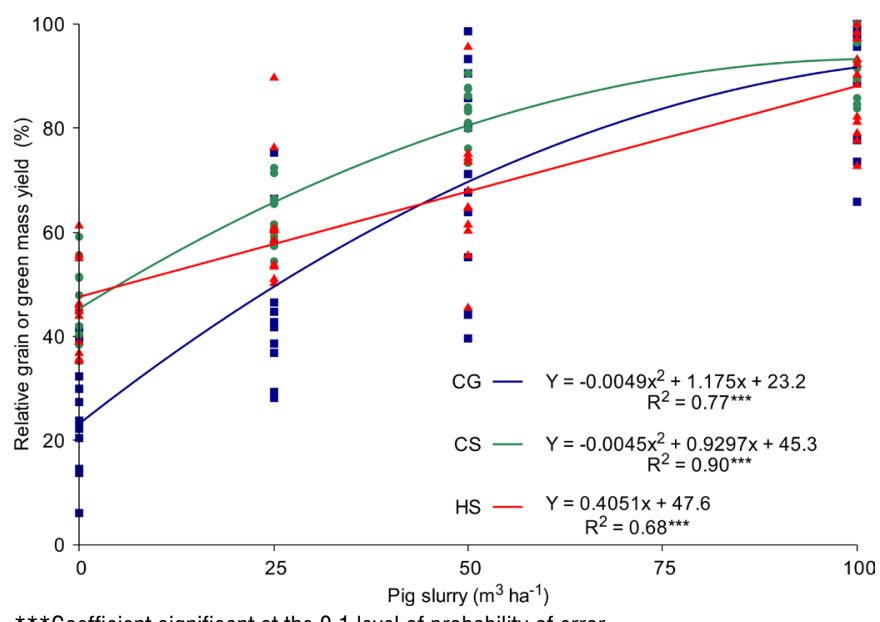

$\star * *$ Coefficient significant at the 0.1 level of probability of error

CG - Keeping the shoot biomass of winter pasture and removing summer crop grain; CS Keeping the shoot biomass of winter pasture and removing that from the summer crops; HS: removing shoot biomass of both winter pasture and summer crops

Figure 3. Relative grain or green mass yield of summer crops in three management systems of shoot biomass in response to doses of pig slurry (PS) effect. This indicates that, conducting the experiment for a longer period, the effect of biomass removal of winter and summer crops in HS system may require higher doses of PS than in the CG system, e.g., the dose response may be greater in the HS system compared with others. Thus, removal of the biomass of winter and summer crops in this system will lead to a sharper decrease in soil fertility than in CG and CS systems, with the application of the dose allowed by the legislation. The CG system, which fully retains residues of winter and summer crops in the field, as well as the CS system, which maintains the residues of winter crops, allows the recycling of PS nutrients to return in greater proportion to the soil along with residues. According to Coelho (2006), problems of soil fertility will be observed earlier in silage than in grain production, due to the removal of the vegetative part and grain in corn silage.

The simplified balance of the nutrients $\mathrm{N}, \mathrm{P}, \mathrm{K}, \mathrm{Ca}+\mathrm{Mg}$, $\mathrm{Cu}$ and $\mathrm{Zn}$ is shown in Figure 4. This balance represents the difference between the amounts of each nutrient applied as PS or AS and the amounts exported by biomass and/or grain of the crops. It was found that there was an excess of $\mathrm{N}$ in all systems with application of AS and PS50, with greater magnitude in PS100. Corn is highly demanding in nutrients and the extraction of soil nutrients by silage occurs in a descending order of $\mathrm{N} \rightarrow \mathrm{K} \rightarrow \mathrm{P} \rightarrow \mathrm{Ca} \rightarrow \mathrm{Mg}$ (Ueno et al., 2013). An excess of $\mathrm{N}$ applied to the soil, through either organic or mineral source, may be subject to loss and contribute to environmental pollution, especially by leaching as $\mathrm{N}$-nitrate (Ceretta et al., 2003), whose magnitude increases with the decrease of clay content in the soil. Different behavior was observed for P, with a small excess only in the CG and CS systems in the PS100, and substantial deficits in others combinations of management systems of shoot biomass and fertilization.

The balances of $\mathrm{K}$ and $\mathrm{Ca}+\mathrm{Mg}$ were similar at doses of both PS and test, but differed in AS because there was no contribution of $\mathrm{Ca}$ and $\mathrm{Mg}$ in this treatment. There was an excess of $\mathrm{K}$ and $\mathrm{Ca}+\mathrm{Mg}$ in the three biomass management systems in the PS100, while in the PS50 it occurred only in the CG system. This may reflect the biomass management, since both $\mathrm{K}$ and $\mathrm{Ca}$ are transferred in smaller amounts to the maize grains and, therefore, remain more in crop residues (Coelho, 2006). This behavior is also reflected in the recommendations for the states of Rio Grande do Sul and Santa Catarina (SBCS, 2004), in which the recommended $\mathrm{K}_{2} \mathrm{O}$ doses are higher for maize and sorghum harvest for silage than for grain in the same class of interpretation of $\mathrm{K}$ content in the soil. Additionally, Ueno et al. (2013) also found, in an Oxisol, that corn harvested for silage exported 384, 228 and $322 \%$ of $\mathrm{K}, \mathrm{Ca}$ and $\mathrm{Mg}$, respectively, compared with the corn harvested for grain. Among types of manure used as sources of nutrients, the PS has the lowest $\mathrm{K}$ content in its composition compared with poultry litter and cattle slurry, reflecting in the $\mathrm{K}$ content remaining in the soil nine years of their application (Veiga et al., 2006). In the CG system, in which only the grain from the summer is harvested and the residues from winter and summer crops remain on the soil, the amounts of $\mathrm{K}$ and $\mathrm{Ca}+\mathrm{Mg}$ that are being applied through PS50 are larger than that removed by the harvested grain. The positive balance indicates that probably $\mathrm{P}, \mathrm{K}, \mathrm{Ca}$ and $\mathrm{Mg}$ are accumulating in the soil, as evidenced by Veiga et al. (2012b) 


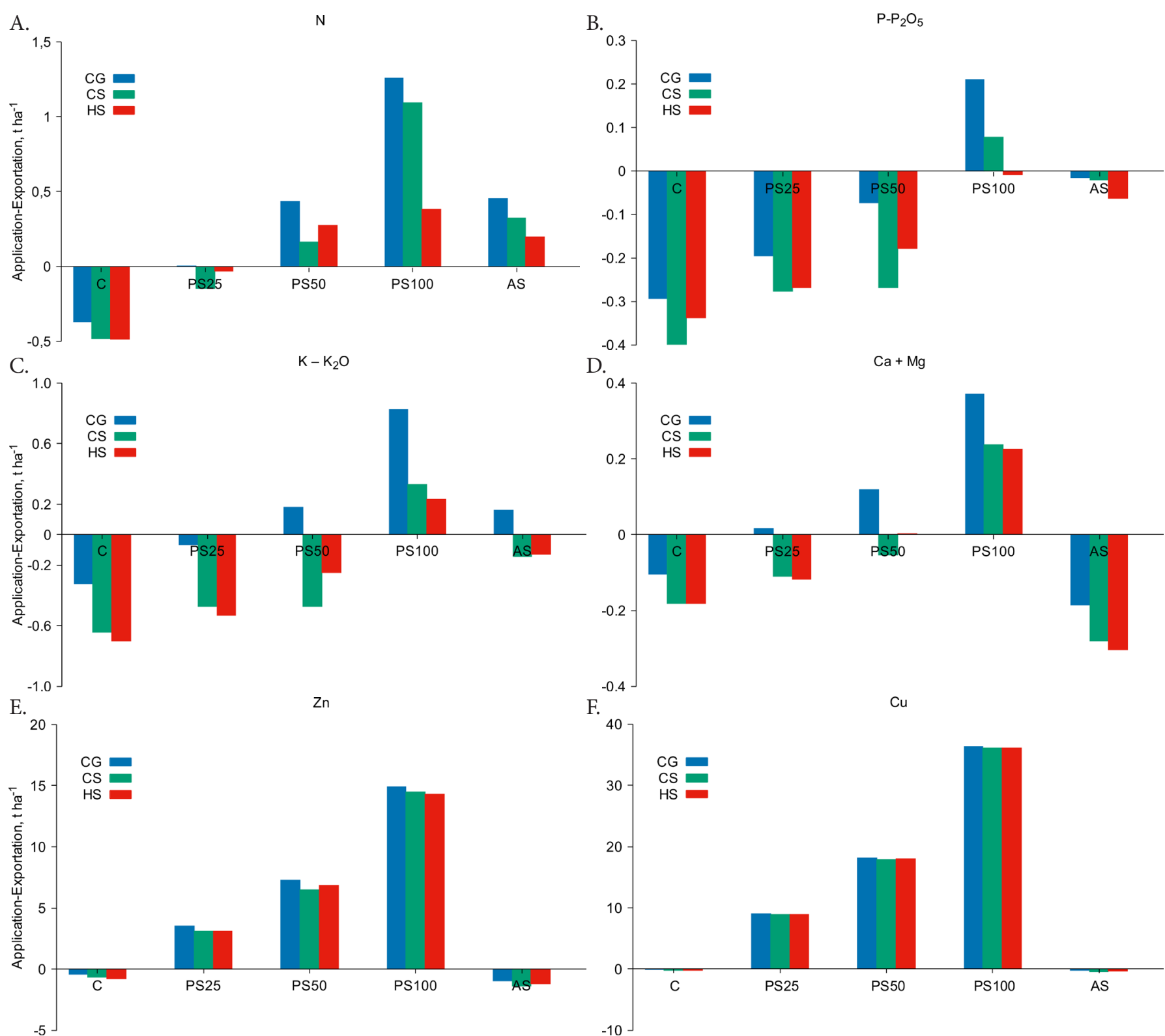

CG - Keeping the shoot biomass of winter pasture and removing summer crop grain; CS - Keeping the shoot biomass of winter pasture and removing that from the summer crops; HS - Removing shoot biomass of winter pasture and of summer crops; C - Control without nutrient application; PS25, PS50 and PS100, respectively 25,50 and $100 \mathrm{~m}^{3}$ ha- ${ }^{-1}$ of pig slurry; AS - $\mathrm{N}$ $\mathrm{P}_{2} \mathrm{O}_{5}$ and $\mathrm{K}_{2} \mathrm{O}$ applied in amounts correspondent to PS50 in the form of soluble fertilizer

Figure 4. Simplified balance of nitrogen $(\mathrm{N})$, phosphorus $(\mathrm{P})$, potassium $(\mathrm{K})$, calcium + magnesium $(\mathrm{Ca}+\mathrm{Mg})$, zinc $(\mathrm{Zn})$ and copper $(\mathrm{Cu})$ as a function of management systems of shoot biomass and fertilization treatments

after nine years of surface application of PS doses in an Oxisol with similar chemical attributes. Regarding the micronutrients $\mathrm{Zn}$ and $\mathrm{Cu}$, only in $\mathrm{C}$ and $\mathrm{AS}$ treatments there was a deficit of these elements because they are not applied through them. The highly positive balance of $\mathrm{Zn}$ and $\mathrm{Cu}$ with the application of PS resulted from the significant amount applied through it (Table 1) and the small amount exported by the crop grain or biomass. Successive applications of PS lead to soil accumulation of $\mathrm{Zn}$ and $\mathrm{Cu}$, especially in bioavailable forms, as evidenced by Girotto et al. (2010) after 17 PS applications in an Ultisol and by Veiga et al. (2012b) after 18 applications in an Oxisol, which may cause environmental impacts such as their transfer to the food chain. Cunha (2009) observed that the Brachiaria brizantha $\mathrm{cv}$. Marandu accumulated $\mathrm{Cu}$ and $\mathrm{Zn}$ in dry matter due to the successive applications of PS in an Oxisol, but without achieving toxic levels to animals. In the same soil class, Veiga et al. (2012a) observed an increase in the Zn content in the biomass of black oat + common vetch and of index leaves of corn with the application of PS, but not in the corn grains. They also observed a positive correlation between the content of this nutrient available in the soil and the total content in the plant tissue.

\section{Conclusions}

1. The management systems of shoot biomass did not affect the yield of the winter pasture. The dry mass yield was also influenced by weather conditions and the composition of the pig slurry.

2. The summer crops responded differently to fertilization treatments and the definition of pig slurry doses for maximum technical efficiency in each biomass management system needs a larger period of observation.

3. In the three management systems of shoot biomass, there was an excess of $\mathrm{Zn}$ and $\mathrm{Cu}$ from the application of 
$25 \mathrm{~m}^{3} \mathrm{ha}^{-1}$ of PS, $\mathrm{N}$ from $50 \mathrm{~m}^{3} \mathrm{ha}^{-1}$ and $\mathrm{P}, \mathrm{K}$ and $\mathrm{Ca}+\mathrm{Mg}$ at the dose of $100 \mathrm{~m}^{3} \mathrm{ha}^{-1}$.

\section{Literature Cited}

Assmann, T. S.; Assmann, J. M.; Cassol, L. C.; Diehl, R. C.; Manteli, C.; Magiero, E. C. Desempenho da mistura forrageira de aveia-preta + azevém e atributos químicos do solo em função da aplicação de esterco líquido de suínos. Revista Brasileira de Ciência do Solo, v.31, p.1515-1523, 2007. http://dx.doi.org/10.1590/S010006832007000600028

Cassol, P. C.; Costa, A. C.; Ciprandi, O.; Pandolfo, C. M. Ernani, P. R. Disponibilidade de macronutrientes e rendimento de milho em Latossolo fertilizado com dejeto suíno. Revista Brasileira de Ciência do Solo, v.36, p.1911-1923, 2012. http://dx.doi.org/10.1590/ S0100-06832012000600025

Ceretta, C. A.; Basso, C. J.; Pavinato, P. S.; Trentin, E. E.; Girotto, E. Produtividade de grãos de milho, produção de matéria seca e acúmulo de nitrogênio, fósforo e potássio na rotação aveia preta/ milho/nabo forrageiro com aplicação de dejeto líquido de suínos. Ciência Rural, v.35, p.1287-1295, 2005. http://dx.doi.org/10.1590/ S0103-84782005000600010

Ceretta, C. A.; Durigon, R.; Basso, C. J.; Barcellos, L. A. R.; Vieira, F. C. B. Características químicas de solo sob aplicação de esterco líquido de suínos em pastagem natural. Pesquisa Agropecuária Brasileira, v.38, p.729-735, 2003. http://dx.doi.org/10.1590/S0100204X2003000600009

Choudhary, L. D.; Bailey, L. D.; Grant, C. A. Review of the use of swine manure in crop production: Effects on yield and composition and on soil and water quality. Waste Management \& Research, v.14, p.581-595, 1996. http://dx.doi.org/10.1177/0734242X9601400606

Coelho, A. M. Nutrição e adubação do milho. Embrapa Milho e Sorgo. 2006. <http://www.cnpms.embrapa.br/publicacoes/publica/2006/ circular/ Circ 78. pdf>. 19 Nov 2013.

Cunha, J. L. Impacto ambiental em sistema de pastagem sob aplicações de esterco líquido de suínos. Uberlândia: Instituto de Geografia/ UFU, 2009. 71p. Tese Doutorado

Delougherty, R. L.; Crookston, R. K. Harvest index of corn affected by population, density, maturity rating, and environment. Agronomy Journal, v.71, p.577-580, 1979. http://dx.doi.org/10.2134/ agronj1979.00021962007100040014x

Fageria, N. K. Otimização da eficiência nutricional na produção das culturas. Revista Brasileira de Engenharia Agrícola e Ambiental, v.2, p.6-16, 1998.

FATMA - Fundação do Meio Ambiente. Instrução Normativa 11. 2009. <http://www.fatma.sc.gov.br> 19 Nov 2011.

Girotto, E.; Ceretta, C. A.; Brunetto, G.; Santos, D. R.; Silva, L. S.; Lourenzi, C. R.; Lorensini, F.; Vieira, R. C. B.; Schmatz, R. Acúmulo e formas de cobre e zinco no solo após aplicações sucessivas de dejeto líquido de suínos. Revista Brasileira de Ciência do Solo, v.34, p.955965. 2010. http://dx.doi.org/10.1590/S0100-06832010000300037
Khaliq, T.; Mahmood, T.; Kamal, J.; Massod, A. Effectiveness of farmyard manure, poultry manure and nitrogen for corn (Zea mays L.) productivity. International Journal of Agriculture \& Biolology, v.6, p.260-263, 2004.

Sartor, L. R.; Assmann, L.; Assmann, T. S.; Bigolin, P. E.; Miyazawa, M.; Carvalho, P. C. F. Effect of swine residue rates on corn, common bean, soybean and wheat yield. Revista Brasileira de Ciência do Solo, v.36, p.661-669, 2012. http://dx.doi.org/10.1590/S010006832012000200035

SBCS - Sociedade Brasileira de Ciência do Solo. Comissão de Química e Fertilidade do Solo. Manual de adubação e calagem para os Estados do Rio Grande do Sul e de Santa Catarina. 10.ed. Porto Alegre: SBCS/NRS, 2004. 400p.

Scheffer-Basso, S. M.; Scherer, C. V.; Ellwanger, M. F. Resposta de pastagens perenes à adubação com chorume suíno: Pastagem natural. Revista Brasileira de Zootecnia, v.37, p.221-227, 2008. http://dx.doi.org/10.1590/S1516-35982008000200007

Scherer, E. E.; Aita, C.; Baldissera, I. T. Avaliação da qualidade do esterco líquido de suínos da região Oeste Catarinense para fins de utilização como fertilizante. Florianópolis: EPAGRI, 1996. 46p. Boletim Técnico, 79

Scherer, E. E.; Baldissera, I. T.; Miranda, M. Produção e qualidade de forragem e atributos do solo influenciados por adubação orgânica e nitrogenada. Florianópolis: EPAGRI, 2012. 50p. Boletim Técnico, 157

Scherer, E. E.; Baldissera, I. T.; Nesi, C. N. Propriedades químicas de um Latossolo Vermelho sob plantio direto e adubação com esterco de suínos. Revista Brasileira de Ciência Solo, v.31, p.123131, 2007. http://dx.doi.org/10.1590/S0100-06832007000100013

Scherer, E. E.; Nesi, C. N.; Massotti, Z. Atributos químicos do solo influenciados por sucessivas aplicações de dejetos suínos em áreas agrícolas de Santa Catarina. Revista Brasileira de Ciência Solo, v.34, p.1375-1383, 2010. http://dx.doi.org/10.1590/S010006832010000400034

Ueno, R. K.; Neumann, M.; Marafon, F.; Reinehr, L. L.; Poczynek, M.; Michalocicz, L. Exportação de macronutrientes do solo em área cultivada com milho para alimentação de bovinos confinados. Semina: Ciências Agrárias, v.34, p.3001-3018, 2013. http://dx.doi. org/10.5433/1679-0359.2013v34n6p3001

Veiga, M.; Pandolfo, C. M.; Balbinot Júnior, A. A. Cobre e zinco no solo e no tecido vegetal após nove anos de uso de fontes de nutrientes associadas a sistemas de manejo em um Nitossolo Vermelho. Agropecuária Catarinense, v.25, p.79-84, 2012a.

Veiga, M.; Pandolfo, C. M.; Balbinot Júnior, A. A.; Spagnollo, E. Chemical attributes of a Hapludox soil after nine years of pig slurry application. Pesquisa Agropecuária Brasileira, v.47, p.1766-1773, 2012b. http://dx.doi.org/10.1590/S0100-204X2012001200013

Veiga, M.; Reinert, D. J.; Pandolfo, C. M. Efeito de sistemas de preparo e de fontes de nutrientes sobre a fertilidade do solo e o crescimento e produção de milho. Agropecuária Catarinense, v.19, p.69-73, 2006. 